\title{
Effects of nitrogen concentrations in turtlegrass Thalassia testudinum on consumption by the bucktooth parrotfish Sparisoma radians
}

\author{
M. E. Goecker*, K. L. Heck Jr., J. F. Valentine \\ Dauphin Island Sea Lab, University of South Alabama, 101 Bienville Boulevard, Dauphin Island, Alabama 36528, USA
}

\begin{abstract}
Terrestrial herbivores often preferentially consume plants that have higher nitrogen concentrations. In these circumstances, low nitrogen concentrations in exposed tissues would be an effective defense against herbivory. In marine environments, the relationship between nitrogen concentration in plants and herbivore preferences has only recently been explored, and results are inconsistent. We examined preferences of the bucktooth parrotfish Sparisoma radians for the turtlegrass Thalassia testudinum with high or low nitrogen concentrations in both field and laboratory experiments. These species were chosen for study because (1) turtlegrass, the dominant seagrass in the Caribbean, is the primary food resource of the bucktooth parrotfish and (2) S. radians is known to be undeterred by the chemical defenses (i.e. phenolic compounds) and physical defenses (i.e. tough tissues) of $T$. testudinum. In field choice experiments, we found that $S$. radians consumed a greater proportion of $T$. testudinum shoots with high nitrogen concentrations than shoots with low nitrogen concentrations (68 vs $5 \%$ ). Similarly, in laboratory experiments, $S$. radians consumed more $T$. testudinum with high nitrogen than with low nitrogen concentrations ( 25 vs $5 \%$ ). To determine whether $S$. radians used the color or shape of shoots as a basis for its preferences, we repeated laboratory experiments using an agar mixture with powdered $T$. testudinum leaves of either high or low nitrogen concentration. S. radians again showed a significant preference for the high nitrogen food source. We, therefore, conclude that mechanisms for choice of high nitrogen food were most likely related to gustation and/or olfaction of chemical cues (i.e. nitrogen or phenols).
\end{abstract}

KEY WORDS: Herbivory $\cdot$ Nitrogen concentration $\cdot$ Seagrass $\cdot$ Parrotfish $\cdot$ Phenolics Resale or republication not permitted without written consent of the publisher

\section{INTRODUCTION}

Herbivores consume substantial quantities of primary production in most marine environments (Cyr \& Pace 1993, Valentine \& Heck 1999, Shurin et al. 2002). As a result, it is widely believed that marine plants have evolved both morphological and chemical defenses that reduce their palatability to herbivores (Hay \& Fenical 1988, Hay et al. 1994, Steneck \& Dethier 1994). Morphological defenses have been studied extensively (e.g. Littler \& Littler 1980, Littler et al. 1983, Duffy \& Hay 1990) and include concentrated compounds in cell walls that make tissues tough and indigestible, as well as alterations in form that reduce susceptibility to herbivore attack (Hay 1984, Steneck \& Dethier 1994). Chemical deterrents such as phenolic acids and condensed tannins are also commonly used by marine macrophytes to reduce their palatability or increase toxicity to herbivores (e.g. Steinberg 1985, Hay et al. 1987, 1994, Hay \& Fenical 1988, Steinberg et al. 1991, Arnold et al. 1995, Targett et al. 1995, Hay 1996). While both morphological and chemical defenses of marine macrophytes have been studied extensively, a third, incompletely studied category of defenses against herbivory involves the reduction of nutritional quality (often measured by plant nitrogen concentration) of plant tissues vulnerable to herbivory attack. 
Studies of terrestrial plant-animal interactions have shown that some herbivores selectively consume plants with high nitrogen concentration in their tissues (e.g. McNeill \& Southwood 1978, Mattson 1980, Schroeder 1986, Athey \& Connor 1989, Minkenberg \& Ottenheim 1989). It has, therefore, been suggested that some plants may reduce the nitrogen concentration of their tissues and thereby cause herbivore preferences to shift to other plants (Moran \& Hamilton 1980). This strategy is thought to be an effective defense against grazing because nitrogen is essential for herbivore growth and reproduction as well as the central role nitrogen plays in cell structure and genetic coding (Mattson 1980).

However, herbivores have strategies to deal with plants that have low nitrogen concentrations. Herbivores can simply increase the amount that they consume (compensatory feeding) or use specialized digestive systems to cope with a nutritionally deficient food resource (Mattson 1980, Lincoln et al. 1982, Slansky 1993). However, increasing the length of time spent feeding could in turn increase herbivore exposure to attack by predators. A simpler and more effective strategy for maximizing herbivore foraging efficiency would be to identify and preferentially consume plants, or parts of plants, that have the highest nitrogen contents (Mattson 1980).

In most western Atlantic tropical and subtropical seagrass meadows, the turtlegrass Thalassia testudinum is the dominant seagrass (Weinstein \& Heck 1979). Morphologically, the flat, strap-like leaves of turtlegrass (Zieman \& Zieman 1989) are thought to be relatively tough. Turtlegrass also contains a mixture of chemical deterrents within its leaves, including condensed tannins (proanthocyanidins) (McMillan 1984), 6 different phenolic acids (Zapata \& McMillan 1979), sulphated phenols and flavones (McMillan et al. 1980), and lignin. These compounds are thought to make turtlegrass leaves unpalatable and toxic to some herbivores, and can also make proteins and carbohydrates unavailable to herbivores (Thayer et al. 1984). In addition, relative to other marine primary producers, T. testudinum leaves are thought to be poor in nutritional quality, with nitrogen concentrations that can be $\leq 1 \%$ (Thayer et al. 1984).

Within Thalassia testudinum meadows, the herbivorous bucktooth parrotfish Sparisoma radians, the smallest species within its genus (average adult length $80 \mathrm{~mm}, \mathrm{TL}$, total length) (Randall 1968), is widespread and abundant (Lobel \& Ogden 1981, Robblee \& Zieman 1984). The toughness of turtlegrass does not seem to deter the strong jaws of the bucktooth parrotfish, as evidenced by crescent shaped bite marks on many turtlegrass leaves. Potential chemical deterrents of T. testudinum are ineffective in reducing the assimila- tion efficiencies of $S$. radians (Targett \& Targett 1990) and their alkaline stomachs allow for dissociation of protein-tannin complexes (Lobel 1981).

Sparisoma radians does display strategies for dealing with the low nitrogen content of turtlegrass. During daylight hours, these fish feed continuously (Lobel \& Ogden 1981, Robblee \& Zieman 1984) on turtlegrass, which constitutes $88 \%$ of their diet (Randall 1968). $S$. radians will increase evacuation rates with low nutritional foods (Targett \& Targett 1990) and they have specialized digestive systems where pharyngeal mills grind plant cell walls to release nutrients (Lobel \& Ogden 1981, Randall 1968).

With morphological and chemical defenses of turtlegrass being ineffective against the bucktooth parrotfish, and with known feeding behaviors associated with low nutrient food resources, we were able set up a model situation for testing if nitrogen concentrations in plants specifically play a role in herbivore choice. To date, few experiments have been designed to test this and where preferential consumption of higher nitrogen plants has been documented, mechanisms and cues that would allow herbivores to make such a choice remain unclear (Stephens \& Krebs 1986, Day et al. 1998). Understanding what cues the consumer receives from prey, whether through ingestion or through external stimuli, will also help in understanding plant defense mechanisms.

Two primary questions were addressed: (1) does Sparisoma radians preferentially choose Thalassia testudinum containing higher nitrogen concentrations and if so, (2) do visual or other cues underlie this choice?

\section{MATERIALS AND METHODS}

Field based feeding preference experiments. Study sites: Experiments were conducted in 3 seagrass meadows within the Florida Keys National Marine Sanctuary (Fig. 1). The New Found Harbor (NFH) $\left(24^{\circ} 36.925^{\prime} \mathrm{N}, 81^{\circ} 23.642^{\prime} \mathrm{W}\right)$ site is an inshore reefassociated seagrass bed approximately $3 \mathrm{~m}$ in depth. NFH is a Sanctuary Preservation Area (SPA), in which no harvesting of marine life is allowed. This site is located just south of Little Palm Island (LP) and the meadow is dominated by Thalassia testudinum. The second site, Looe Key (LK) $\left(24^{\circ} 32.830^{\prime} \mathrm{N}\right.$, $81^{\circ} 23.642^{\prime} \mathrm{W}$ ), is also a SPA and is located $11.3 \mathrm{~km}$ offshore of Big Pine Key. This seagrass bed is behind a well-developed reef and is also approximately $3 \mathrm{~m}$ in depth. It is dominated by $T$. testudinum, although Syringodium filiforme is also present. The last site was located just off the beach of LP $\left(24^{\circ} 37.258^{\prime} \mathrm{N}\right.$, $\left.81^{\circ} 24.324^{\prime} \mathrm{W}\right)$, bordering Big Pine Key boat channel. 


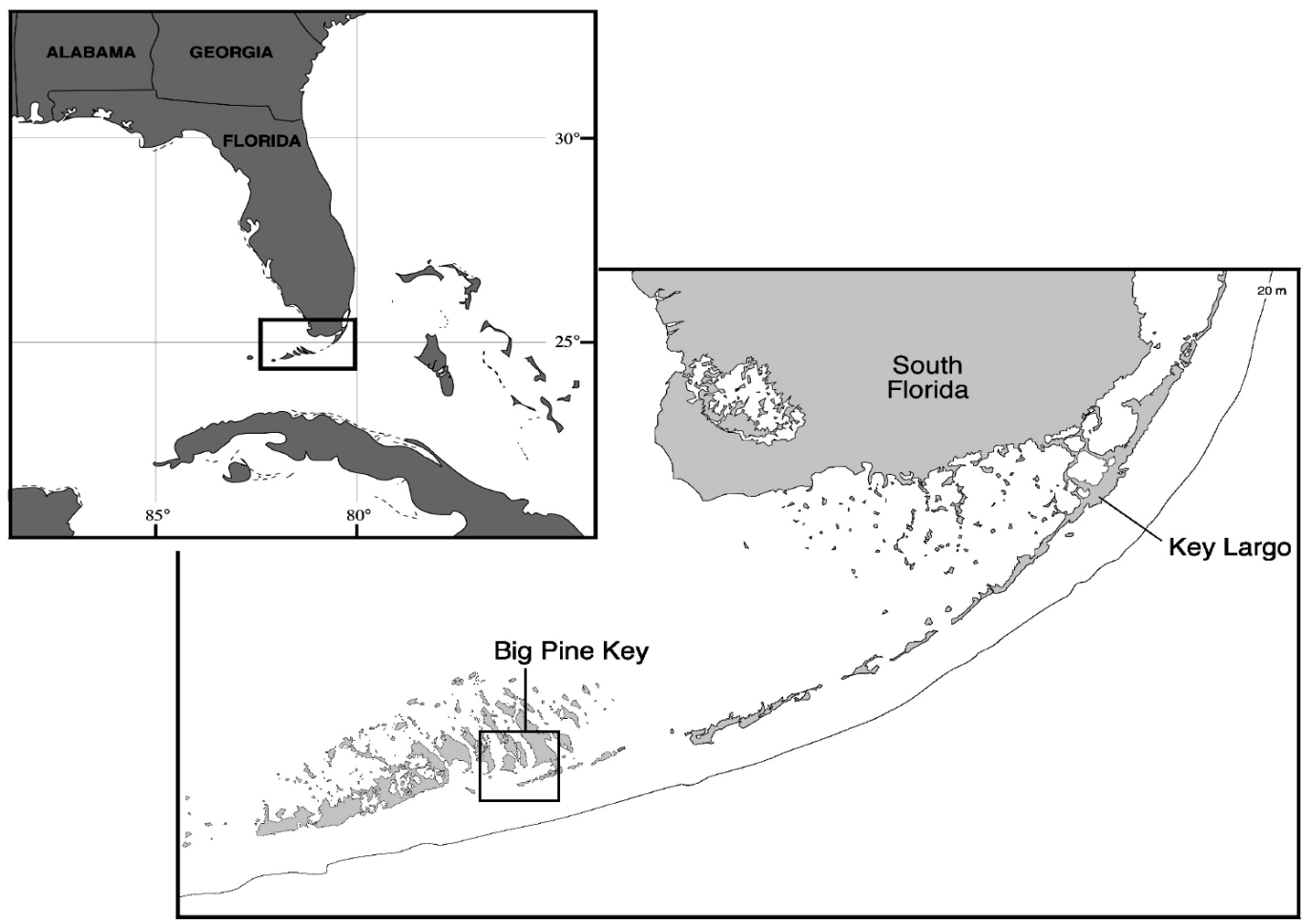

Fig. 1. Study site locations in Florida Keys, USA

This site is not reef-associated, is dominated by T. testudinum and is shallow (1 to $2 \mathrm{~m}$ ) with some areas exposed during low tide. Sparisoma radians were abundant at all 3 sites.

Experimental procedure: Thalassia testudinum shoots containing high and low nitrogen concentrations were collected daily and used in experiments the following day. All leaves on each seagrass shoot were severed at the top of the sheath and examined for bite marks. If bite marks were present, the damaged portion of the leaf was removed to provide uniformity in leaf appearance. All leaves on a shoot were then scanned using a flatbed scanner (Hewlett Packard). Leaves were then reassembled into 'shoots' and 3 'shoots' of high or low nitrogen concentration were attached to a sisal rope (a 'tether') with clips (see methods in Kirsch et al. 2002). Five of both low and high nitrogen tethers, each containing 3 shoots, were placed at all 3 sites. Tethers were deployed for a $24 \mathrm{~h}$ period and then retrieved and rescanned. This process was repeated for $5 \mathrm{~d}$ at each site during June 2002 and repeated for $3 \mathrm{~d}$ at each site in July 2002 $(\mathrm{n}=8)$. Sigma-Scan Pro image analysis software (SPSS) was used to determine the area of the scanned seagrass leaf images before and after deployment (Fig. 2) and to estimate the percent area lost due to herbivory.
Statistical analyses: Treatment effects at each site were analyzed separately using $t$-tests, where days were replicates. Sites were treated separately to determine whether similar patterns in herbivory occurred in differing seagrass meadows. Differences in daily rates of herbivory between June and July at each site were evaluated for both high and low nitrogen Thalassia testudinum.

Consistent with the one-sided alternative hypothesis that higher nitrogen concentrations within the plant would experience higher rates of herbivory (Rice \& Gaines 1994), a one-tailed $t$-test for within site comparisons was performed on the percent of leaf area lost to herbivory for high and low nitrogen Thalassia testudinum. Data on percent nitrogen $(\bar{x} \pm 1 \mathrm{SE})$ at the experimental sites were also compared using $t$-tests.

Seagrass collection: High nitrogen Thalassia testudinum shoots were harvested from a residential boat canal in Big Pine Key, Florida. This site is highly eutrophied, mostly due to nutrient input from leaky residential septic tanks (LaPointe \& Matzie 1996). Low nitrogen $T$. testudinum shoots were collected from the seagrass bed at LP. Use of seagrass from locations other than the experimental sites has been previously shown to have no observable artifacts. For example, Kirsch et al. (2002) found no significant difference in the proportion of net annual primary production 


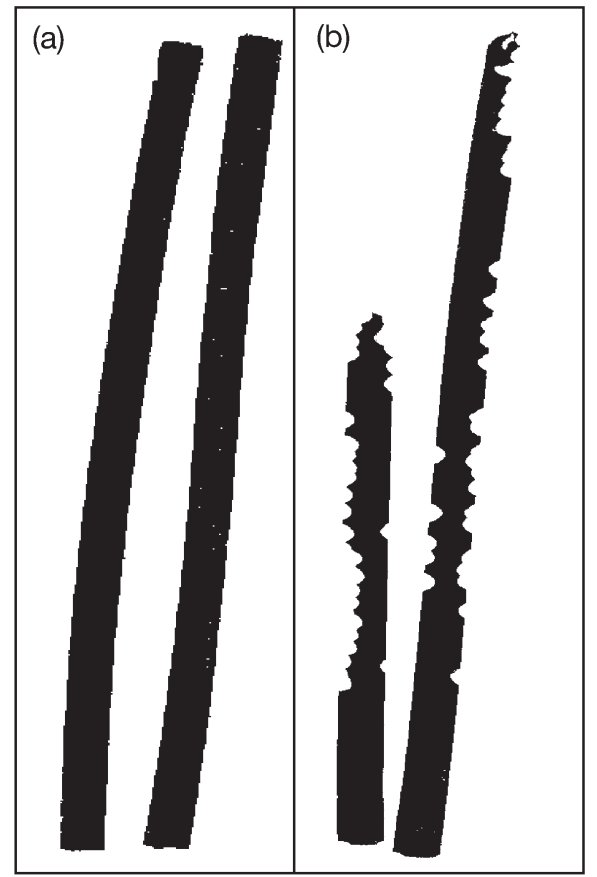

Fig. 2. Thalassia testudinum leaves that contained high concentrations of nitrogen (a) before deployment and (b) after deployment

(NAPP) consumed by grazers when using seagrass that differed in either leaf shape or size from seagrass growing at their individual study sites.

To ensure that seagrass from the Big Pine Key canal had significantly higher nitrogen concentrations than the seagrass from the experimental sites, 5 shoots from all sites were collected in June and July 2002, and were dried at $60^{\circ} \mathrm{C}$, ground with mortar and pestle, and analyzed using the NA1500 C/N/S analyzer ${ }^{\mathrm{TM}}$ (Carlo Erba) prior to beginning experiments.

A pilot study was performed to verify that the nitrogen concentration of Thalassia testudinum shoots did not change subsequent to harvesting and before use in experiments. Seagrass shoots containing both high and low concentrations of nitrogen were harvested and placed in a bucket of seawater. At 0, 6, 12, 24, 48 and $72 \mathrm{~h}$ after harvesting, 10 randomly selected shoots were removed from the bucket. The leaves were severed just above the leaf sheath, dried at $60^{\circ} \mathrm{C}$, ground and analyzed using the NA1500 C/N/S analyzer ${ }^{\mathrm{TM}}$ (Carlo Erba). Results showed no significant reduction in nitrogen concentrations over $72 \mathrm{~h}$ for either the high nitrogen T. testudinum (slope: $-0.0013, \mathrm{r}^{2}=0.11, \mathrm{p}=$ 0.10 ) or the low nitrogen T. testudinum (slope: +0.0013 , $\mathrm{r}^{2}=0.07, \mathrm{p}=0.20$ ).

Before use in experiments, Thalassia testudinum leaves were wiped once by hand to remove any large epiphytes, but small, adherent epiphytes were not scraped off, since herbivores are usually presented with epiphytized leaves in their natural environment. For this reason, a shoot will be defined as the leaves and associated epiphytes. Both the leaves and epiphytes of the high and low T. testudinum treatments were analyzed for nitrogen concentration. Epiphytes attached to the low nitrogen $T$. testudinum had less nitrogen content than their associated leaves (epiphytes, $0.95 \pm 0.08 \%$; leaves, $2.02 \pm 0.09 \%, \mathrm{n}=5$ ) and epiphytes attached to the high nitrogen $T$. testudinum had similar nitrogen concentrations to their leaves (epiphytes, $2.36 \pm 0.16 \%$; leaves, $2.24 \pm 0.12 \%, \mathrm{n}=5$ ). Because these epiphytes seem to reflect the nitrogen concentration of the shoot, any choice by herbivores based on nitrogen concentration should not be confounded by epiphytes.

Laboratory feeding preference experiments. To determine whether similar results occurred as in field experiments, as well as to determine feeding rates of fish on high and low nitrogen, Thalassia testudinum, preference tests were conducted in a controlled laboratory setting. Altogether, approximately 200 adult Sparisoma radians were collected with a $7 \mathrm{~m}$ bag-seine from the seagrass meadow at LP for use in the laboratory experiments. Average fish size was $79.86 \pm 12.91 \mathrm{~mm}$ total length (TL) and the range was 59 to $110 \mathrm{~mm}$ TL. Approximately 30 specimens at a time were captured and transported to the Mote Marine Laboratory on Summerland Key, Florida, where they were placed in holding tanks containing Thalassia testudinum. Specimens were allowed $16+\mathrm{h}$ to acclimate to laboratory conditions and were allowed to feed ad libitum on turtlegrass containing low nitrogen concentration that was both anchored to the bottom and floating on the top of the tank. After acclimation, and before use in experiments, fish were placed in a tank containing artificial seagrass mats made of Vexar mesh and green ribbon for a starvation period of 16 to $24 \mathrm{~h}$ (Lobel \& Ogden 1981).

Experiments were conducted in 37.81 flowthrough tanks with sand bottoms. Tanks were divided in half with Vexar mesh, thereby allowing 2 experiments per tank to be conducted simultaneously. Thalassia testudinum containing high and low concentrations of nitrogen were collected from the same sites as those used in the field studies. Shoots area was determined as previously described, but this time 'shoots' were formed by clipping leaves together with binder clips. Four of these clips, each containing a $T$. testudinum shoot, were pushed into the sand at evenly spaced intervals in the tanks and 1 fish was used per trial. Three experiments were carried out. The first was a preference test in which fish were presented a choice between 2 high and 2 low nitrogen shoots. The second and third experiments were 'no-choice' tests, which consisted of either 
4 high nitrogen or 4 low nitrogen shoots separately. 'No-choice' experiments were performed to determine if feeding rates were affected by leaf nitrogen concentrations (a compensatory feeding response).

Fish were allowed to feed for $2 \mathrm{~h}$. Pilot experiments (data not shown) demonstrated that this was sufficient to allow Sparisoma radians to acclimate to a new tank and to initiate feeding. After $2 \mathrm{~h}$, seagrass shoots were removed from the tank and rescanned to determine the area consumed. 'Choice' trials were repeated 38 times and 'no-choice' trials were repeated 36 times.

A paired 1-tailed $t$-test was performed on data from the 'choice' experiments to compare percent area lost $(\bar{x} \pm 1 \mathrm{SE})$ due to herbivory between plants containing high and low concentrations of nitrogen. A 1-tailed $t$ test was performed for 'no-choice' treatments. Prior to analysis, square root transformation was applied to satisfy the assumptions of normality and equal variance.

Laboratory experiments for visual cues. To determine whether Sparisoma radians used differences in leaf color (as seen by the human eye) and/or shape to distinguish between Thalassia testudinum that contained high or low concentrations of nitrogen, the experimental protocols described above were repeated with ground T. testudinum leaves embedded in an agar matrix. Methods used for making agar mixtures were adopted from Hay (1984). T. testudinum shoots with high and low concentrations of nitrogen were harvested, all leaves cut above the leaf sheath, dried and ground into powder with mortar and pestle. A small amount $(1 \mathrm{~g})$ of ground T. testudinum was placed in a heated mixture of 20 to $25 \mathrm{ml}$ of distilled water and $0.3 \mathrm{~g}$ of agar. This mixture was poured into an acrylic mold shaped like a T. testudinum leaf. Fiberglass window screening was placed in the agar mold to provide support for the agar strip and to provide an anchoring point for the binding clips. The amount of material consumed by $S$. radians was determined by the difference of the wet weights of the agar strips before and after each experiment. To estimate potential wet weight losses of agar strips during experiments, wet weights before and after within control treatments containing no herbivores were taken for both high and low nitrogen agar strips.

A paired 1-tailed $t$-test was performed on data from the 'choice' experiments to compare wet weight lost (agar) $(\bar{x} \pm 1 \mathrm{SE})$ due to herbivory between high and low nitrogen content food sources. A 1-tailed $t$-test was performed for 'no-choice' treatments to compare differences in ingestion rates when no choice was available. The wet weights of agar strip controls before and after experimental periods were also compared using a $t$-test.

Analytical problems can occur when performing preference tests (Peterson \& Renaud 1989, Roa 1992, Manly 1993). The 2 main concerns are: (1) lack of independence in food types offered simultaneously and (2) autogenic changes (i.e. growth, mortality, reproduction) that may occur during experimentation. Although this study is not exempt from the problem of independence, the outcomes of these experiments are clear-cut and, as noted by Roa (1992), are most likely 'robust to many errors'. As for the second concern, there was very limited autogenic change over the short experimental times (see below), which simplified the estimation of consumption (Peterson \& Renaud 1989).

Determination of total reactive phenolics. Phenolic compounds may affect herbivore digestion and nutrition, but not all phenolic compounds act as deterrents to all herbivores. Phenolic compounds, although they do not affect Sparisoma radians assimilation efficiencies (Targett \& Targett 1990), may be a cue that influences food choice and, therefore, knowledge of the presence of these compounds may be important when considering the reasons for herbivore choice.

To investigate the potential influence of phenolic concentrations, shoots of Thalassia testudinum with high and low concentrations of nitrogen were harvested in August 2002 from the study sites used in the laboratory and field experiments. To prevent changes in the phenolic content of leaves following harvest, shoots were placed on ice and transported to the laboratory where they were stored at $-80^{\circ} \mathrm{C}$. Sections of $3 \mathrm{~cm}$ were cut $\sim 3 \mathrm{~cm}$ from the top of the second youngest leaf of both high and low nitrogen $T$. testudinum $(\mathrm{n}=18)$, because the top half of the blade was where most herbivory was observed. If epiphytes were present, they were scraped from samples. If lesions were present, sections were taken at least $2 \mathrm{~cm}$ away from them. Sections were placed into micro-centrifuge tubes and freeze dried for $8 \mathrm{~h}$. Samples were then transported on dry ice to the College of Charleston where the total reactive and extractable phenolics were measured using the Folin Assay as described by Arnold \& Schultz (2001). A $t$-test was used to test for differences in phenolic concentrations in leaves from high and low nitrogen treatments.

\section{RESULTS}

\section{Field based feeding preference experiments}

Shoots from the Big Pine Key residential canal contained significantly more nitrogen than shoots collected from LP in both months (Table 1). In addition, Thalassia testudinum at all 3 study sites had significantly lower nitrogen than the high nitrogen T. testudinum from the Big Pine Key residential canal in both months (Table 1).

Rates of herbivory between June and July did not differ significantly for treatments containing high or 
Table 1. Percent nitrogen $( \pm$ SE) of the Big Pine Key Canal and experimental sites for June and July. Significant differences were found between the Thalassia testudinum at the Big Pine Key Canal (high nitrogen treatment) and the T. testudinum at all 3 sites for both months

\begin{tabular}{|lcccc|}
\hline & Big Pine Key Canal & Little Palm Island & New Found Harbor & Looe Key \\
\hline June $\bar{x} \pm$ SE & $2.14 \pm 0.01$ & $1.80 \pm 0.03$ & $1.13 \pm 0.09$ & $0.92 \pm 0.04$ \\
July $\bar{x} \pm$ SE & $2.14 \pm 0.05$ & $(t=-12.03, \mathrm{p}<0.001)$ & $(t=10.76, \mathrm{p}<0.001)$ & $(t=-31.20, \mathrm{p}<0.001)$ \\
& & $1.58 \pm 0.04$ & $1.14 \pm 0.03$ & $1.17 \pm 0.03$ \\
& $(t=8.83, \mathrm{p}<0.001)$ & $(t=16.81, \mathrm{p}<0.001)$ & $(t=-8.83, \mathrm{p}<0.001)$ \\
\end{tabular}

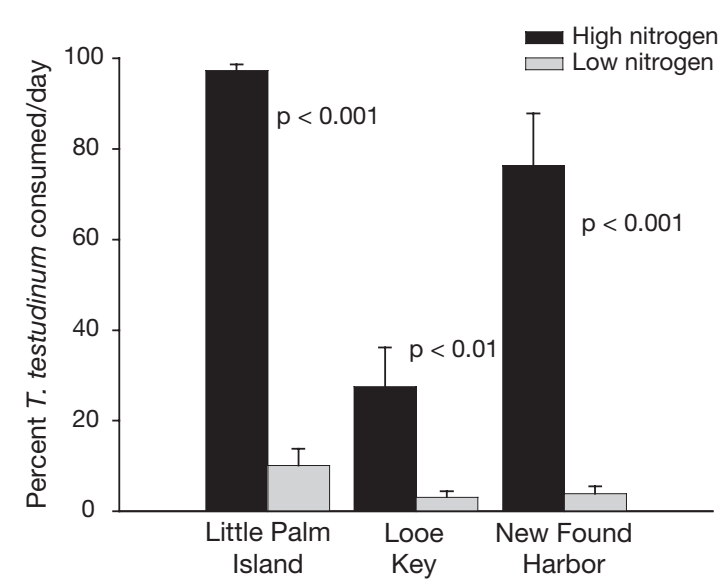

Fig. 3. Percent Thalassia testudinum consumed $d^{-1}(\bar{x} \pm 1 \mathrm{SE})$ at the study sites

low concentrations of nitrogen at all 3 sites $(\mathrm{p}>0.05)$; therefore, daily replicates from June and July were pooled $(n=8)$. One day was lost in July at LK due to inclement weather; thus, LK had only 7 replicates. Sparisoma radians consumed substantially and significantly more high than low nitrogen Thalassia testudinum at all 3 sites (LP, $t=22.38, \mathrm{df}=14, \mathrm{p}<0.001$; LK, $t=3.02, \mathrm{df}=13, \mathrm{p}<0.01 ; \mathrm{NFH}, t=7.57, \mathrm{df}=14, \mathrm{p}<$ 0.001) (Fig. 3). For example, at LP, on average, some $97 \%$ of the leaf area of high nitrogen seagrass was consumed whereas the mean consumption of low nitrogen shoots was only $10 \%$. At NFH, the mean percentage of high nitrogen $T$. testudinum shoots consumed was almost $80 \%$ whereas the mean consumption of low nitrogen shoots was just $3 \%$. At LK, the mean percentage of high nitrogen $T$. testudinum shoots consumed was $27 \%$ and the mean percentage of low nitrogen shoots consumed was $3 \%$.

\section{Laboratory feeding preference experiments}

When Sparisoma radians was offered a choice between Thalassia testudinum of high and low nitrogen concentrations ('choice' experiments), the fish showed a significant preference for high nitrogen
T. testudinum $(t=7.89, \mathrm{df}=37, \mathrm{p}<0.001)$. At the end of the $2 \mathrm{~h}$ feeding trial, over 5 times more high nitrogen T. testudinum was consumed, on average, than T. testudinum with low nitrogen concentrations (Fig. 4).

When Sparisoma radians was offered Thalassia testudinum with either high or low nitrogen concentrations ('no-choice' experiments), high nitrogen T. testudinum was consumed at a significantly higher rate $(t=2.56, \mathrm{df}=70, \mathrm{p}<0.01)$. The mean percentage of T. testudinum containing high nitrogen that was consumed was $16.6 \pm 1.8 \%$, while the mean percentage of T. testudinum containing low nitrogen that was consumed was $10.7 \pm 1.4 \%$ (Fig. 4).

\section{Laboratory experiments for visual cues}

We found no significant losses of agar in control experiments $(p>0.3)$, therefore, there was no need to

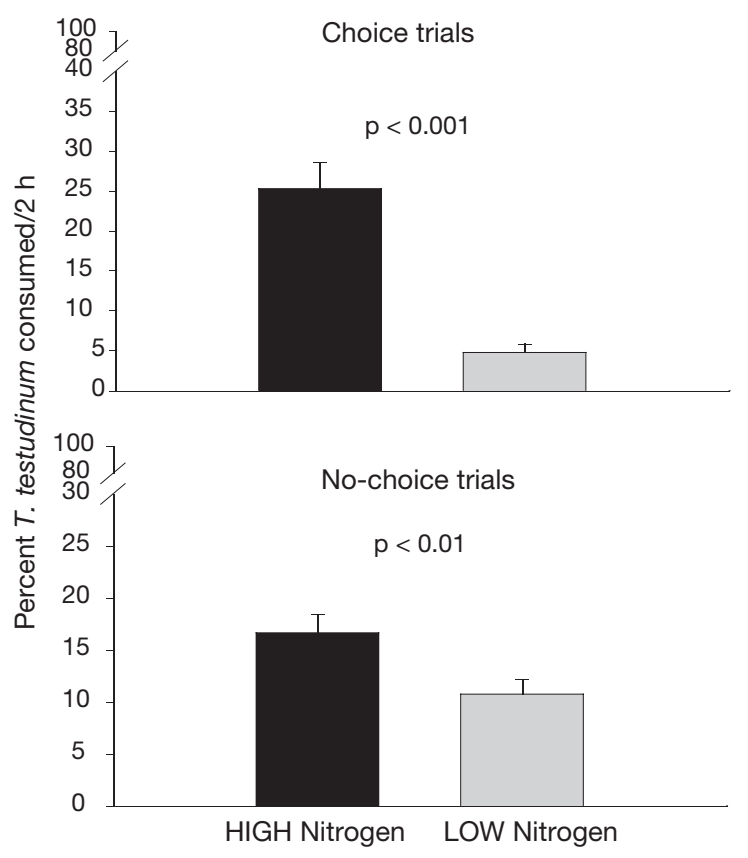

Fig. 4. Percent Thalassia testudinum consumed per $2 \mathrm{~h}$ $(\bar{x} \pm 1 \mathrm{SE})$ in laboratory 'choice' and 'no-choice' experiments 
Table 2. Wet weights of agar controls (no herbivore present) before and after trial for high nitrogen, low nitrogen, and high and low nitrogen agar together

\begin{tabular}{|lccc|}
\hline & $\begin{array}{c}\text { High } \\
(\mathrm{n}=35)\end{array}$ & $\begin{array}{c}\text { Low } \\
(\mathrm{n}=45)\end{array}$ & $\begin{array}{c}\text { Both } \\
(\mathrm{n}=80)\end{array}$ \\
\hline $\bar{X} \pm$ SE before & $2.05 \pm 0.06$ & $2.38 \pm 0.06$ & $2.23 \pm 0.05$ \\
$\bar{X} \pm$ SE after & $1.95 \pm 0.07$ & $2.35 \pm 0.06$ & $2.17 \pm 0.05$ \\
& $(t=1.03$, & $(t=0.31$, & $(t=0.83$ \\
& $\mathrm{p}=0.31)$ & $\mathrm{p}=0.76)$ & $\mathrm{p}=0.41)$ \\
\hline
\end{tabular}

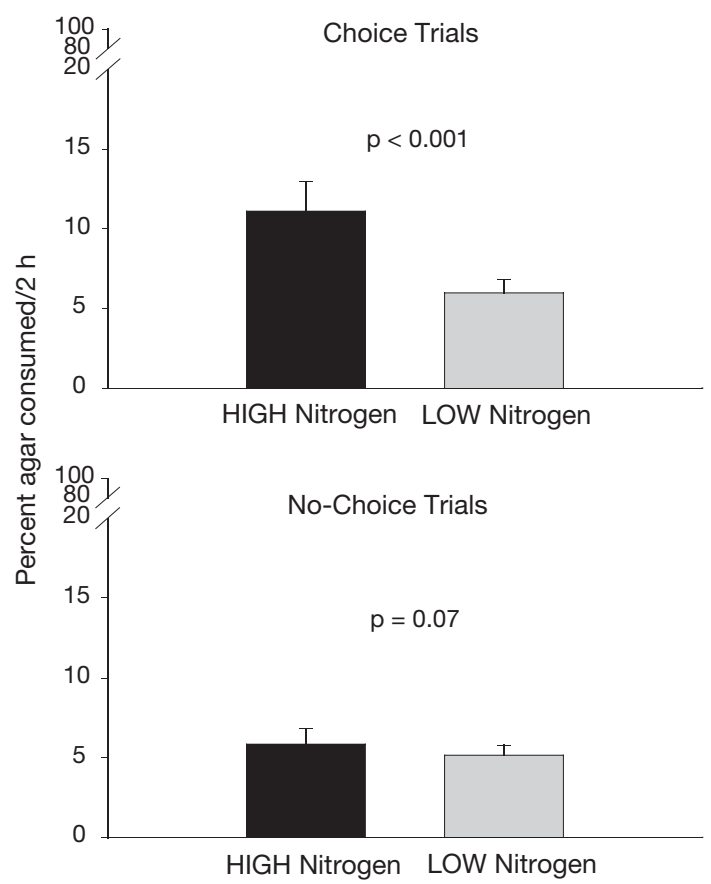

Fig. 5. Percent agar consumed per $2 \mathrm{~h}(\overline{\mathrm{x}} \pm 1 \mathrm{SE})$ in laboratory 'choice' and 'no-choice' experiments

correct for changes in wet weight of the agar in these experiments (Table 2). Sparisoma radians showed a significant preference for agar containing high nitrogen leaves $(t=4.01, \mathrm{df}=32, \mathrm{p}<0.001)$ in 'choice' experiments (Fig. 5). In 'no-choice' experiments, $S$. radians consumed slightly more high than low nitrogen agar but the difference was not significant $(t=1.52, \mathrm{df}=65, \mathrm{p}=0.07$ ) (Fig. 5).

\section{Analysis of total reactive phenolics in Thalassia testudinum}

High nitrogen Thalassia testudinum contained $2.6 \pm$ $0.3 \mu \mathrm{g}$ phenols $\mathrm{mg}$ tissue ${ }^{-1}$ whereas the low nitrogen T. testudinum contained $10.6 \pm 1.0 \mu \mathrm{g}$ phenols $\mathrm{mg}$ tissue $^{-1}$, and these differences were significant $(t=$ 7.38, $\mathrm{df}=30, \mathrm{p}<0.001$ ) (Fig. 6).

\section{DISCUSSION}

Sparisoma radians clearly preferred Thalassia testudinum containing higher concentrations of nitrogen at all field sites and in all laboratory experiments. These findings are consistent with other studies that have reported a similar positive relationship between plant nitrogen concentrations and herbivore grazing intensity (e.g. Bjorndal 1980, Zieman et al. 1984, McGlathery 1995, Preen 1995); however, other studies have not found this same result (Mariani \& Alcoverro 1999, Valentine \& Heck 2001, Kirsch et al. 2002).

Reasons for inconsistencies between prior studies may be due to the inverse relationship between phenolic and nitrogen concentrations that can exist in some, but not all plants (Steinberg 1985, Buchsbaum et al. 1990, Arnold et al. 1995, Peckol et al. 1996, Vergeer \& vander Velde 1997; but see Herms \& Mattson 1992, Ravn et al. 1994, Heckscher et al. 1996, Karban \& Baldwin 1997). Phenolic compounds have been shown to play numerous roles in plants such as providing protection from photodamage (Close \& McArthur 2002) and serving as antimicrobial agents (Vergeer \& Develi 1997), but for the most part, phenolic compounds are considered to be herbivore deterrents. However, conclusions differ on the efficacy of this deterrence (Hay et al. 1987, 1994, Hay \& Fenical 1988, Hay 1996; but see Steinberg 1985, Steinberg et al. 1991, Wakefield \& Murray 1998, Jormalainen et al. 2001). If in fact experimental animals are negatively affected by the presence of phenolic compounds and if the experimental plant's phenolic concentrations covary with nitrogen concentrations, results on the effects of nitrogen content specifically can be confounded.

Our experimental plant Thalassia testudinum has been shown to contain phenolics (Zapata \& McMillan

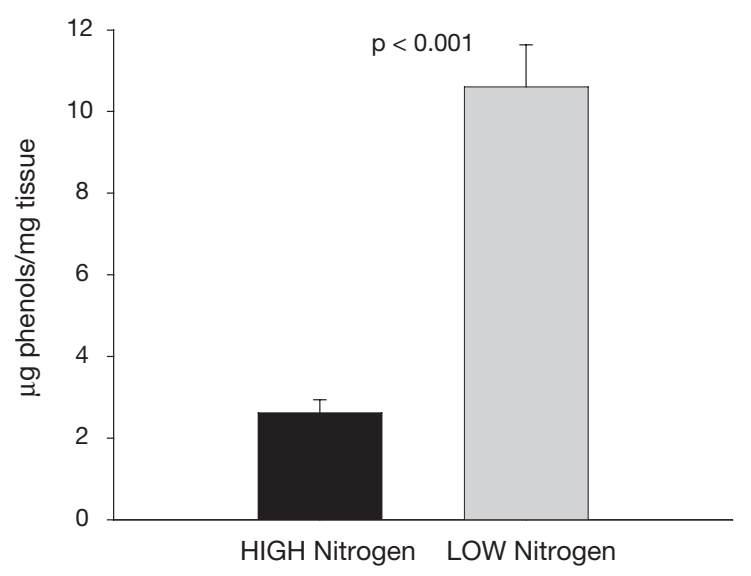

Fig. 6. Total reactive phenolics ( $\mu$ g phenols $m g$ tissue $e^{-1}, \bar{X} \pm$ $1 \mathrm{SE}$ ) present in Thalassia testudinum used for high and low nitrogen treatments 
1979, McMillan et al. 1980, McMillan 1984) and in this study, was shown to have covarying nitrogen and phenolic concentrations (Fig. 6). While this could have affected the way choices were made, Sparisoma radians' assimilation efficiencies and digestion rates are unaffected by phenolic-rich foods due to specialized gut characteristics (Targett et al. 1995). Furthermore, Hay (1984) noted that even though Thalassia sp. contains phenolic compounds, it still experienced high to intermediate rates of consumption by large reef parrotfish. Duffy \& Paul (1992) concluded that nutrients are a more important factor for tropical reef fish choice of algae than the presence of chemical compounds. As a result of this apparent lack of chemical deterrence of bucktooth grazing, we believe that nitrogen concentration was most likely the factor driving feeding preference. Consequently, we conclude that our results show that $S$. radians selectively finds and feeds on food sources with higher nitrogen concentrations and that low nitrogen concentration is a good defense strategy for $T$. testudinum (whether it is induced or constitutive).

Previous studies have suggested that low nitrogen concentration is not always effective due to compensatory feeding (Cruz-Rivera \& Hay 2000, Valentine \& Heck 2001). Compensatory feeding behavior has been previously documented for Sparisoma radians (Targett \& Targett 1990); however, in our laboratory 'no-choice' trials, compensatory feeding was not observed because there was a higher rate of herbivory on the high nitrogen Thalassia testudinum than on the low nitrogen T. testudinum (Fig. 4). Given that compensatory feeding would increase predation risk, the ability of $S$. radians to select $T$. testudinum leaves with relatively high nitrogen concentrations may provide a low predationrisk mechanism for obtaining adequate nutrition.

\section{Mechanisms for choice}

Terrestrial ecologists have hypothesized that animals can learn to recognize plants that change physically (i.e. leaf shape or color) when they contain more nitrogen (Westoby 1974). This may also be the case for marine herbivores. For example, studies have shown that the green algae Cladophora spp. has a different color when grown in high nutrient environments (Norin \& Waern 1973). In our laboratory experiments, removal of visual cues by using uniformly colored and shaped agar leaves suggested that Sparisoma radians did not choose high nitrogen Thalassia testudinum primarily by visual cues detected by the human eye. This is similar to the results of Kirsch et al. (2002), who found that changes in length and width of $T$. testudinum did not lead to differences in the proportion of primary production consumed. Similarly, Steinberg et al. (1991) concluded that morphological characters of algae were not responsible for differences in consumption by herbivorous fish.

Olfaction and gustation are also known to affect feeding behaviors of fish (Bardach \& Atema 1971, Goh \& Tamura 1980, Hara 1994). Most fish are thought to be sensitive to chemicals (i.e. nitrogen and phenolics) in their food source (Bardach \& Atema 1971, Hara 1994). Electrophysiological studies have shown that different amino acids can be detected by both taste and olfactory systems of teleost fish (Marui \& Caprio 1992, Hara 1994, Lamb 2001). Herbivorous fish (e.g. rabbitfish, Siganus fusenscens and redbelly tilapia, Tilapia zillii) have been shown to possess receptors for a wide range of amino acids, such as aspartic and glutamic acids (Hara 1994). Seagrasses experience nutrient losses through leaching by both living and senescent plant material and this could act as a cue for herbivorous fishes (Hemminga et al. 1991).

Observations of Sparisoma radians feeding in the laboratory suggest that they use gustation. When placed in tanks with a choice, both low and high nitrogen shoots of Thalassia testudinum were sampled by $S$. radians, but the fish would repeatedly bite the high nitrogen (low phenolic) leaves (see Fig. 2b). This behavior seems to indicate that the fish was motivated to actively sample different leaves to determine their value. It may be that phenolic compounds can act as a detectable cue for nutritional value rather than a deterrent to some fishes.

Whatever the mechanism used to distinguish among different foods, whether visual, olfactory and/or gustation, the ability to remember past experiences will influence subsequent choices (Day et al. 1998). Fish that show learned behavior are most likely able to associate sensory properties of foods with their metabolic and physiological effects (Forbes 1997, de la Higuera 2001).

\section{Implications of selective feeding}

The ability of marine herbivores to preferentially choose higher nitrogen food sources could influence the outcome of competitive interactions among seagrasses, leading to broad-scale changes in the composition of seagrass meadows. Theoretically, seagrass species composition could shift from dominance by highly nutritious fast growing species to dominance by less nutritious slow growing species. In the Caribbean, this may be the case. Thalassia testudinum is thought to be superior to other seagrass species in competing for sediment nutrients and light (Williams 1987), but T. testudinum may also be able to more effectively deal with intense herbivory through effective growth strategies (Valentine \& Heck 1999) and defense mechanisms such as low nitrogen concentration. 


\section{CONCLUSIONS}

The bucktooth parrotfish Sparisoma radians showed a significant preference for Thalassia testudinum containing high concentrations of nitrogen over $T$. testudinum containing low concentrations of nitrogen in both field and laboratory experiments. Although differences in nitrogen concentration were most likely the primary factor for herbivore choice in the case of the bucktooth parrotfish, future research should consider the possible inverse relationship between nitrogen concentrations and phenolic concentrations, and how this could confound conclusions. The mechanisms for choice were most likely related to gustation and/or olfaction of chemical cues (nitrogen or phenols) and not to visual cues (shape or color). There was no evidence that the bucktooth parrotfish used compensatory feeding strategies.

Acknowledgements. Hours of field work and scanning were made possible by D. Blackmon, J. Christian, B. Peterson, R. Kroutil, G. Fioravanti and C. Wapnick. The Dauphin Island Sea Lab receives thanks for technical support as well as J. Fourqurean for use of instrumentation at Florida International University. Thanks to T. M. Arnold for his added expertise and long hours spent on phenolic analysis. We would also like to thank 3 anonymous reviewers for their helpful comments. This project was supported by the Alabama Center for Estuarine Studies (ACES), the Nature Conservancy's Ecosystem Research Program, the National Marine Fisheries Service (Marfin) and the University of South Alabama.

\section{LITERATURE CITED}

Arnold TM, Schultz JC (2001) Induced sink strength as a prerequisite for induced tannin biosynthesis in developing leaves of Populus. Oecologia 130:585-593

Arnold TM, Tanner CE, Hatch WI (1995) Phenotypic variation in polyphenolic content of the tropical brown algae Lobophora variegata as a function of nitrogen availability. Mar Ecol Prog Ser 123:177-183

Athey L, Connor E (1989) The relationship between foliar nitrogen content and feeding by Odonta dorsalis Thun. on Robinia pseudoacacia (L.). Oecologia 79:390-394

Bardach JE, Atema J (1971) The sense of taste in fishes. In: Autrum H, Jung R, Loewenstein WR, MacKay DM, Teuber HL (eds) Handbook of sensory physiology. SpringerVerlag, Berlin, p 293-336

Bjorndal KA (1980) Nutrition and grazing behavior of the green turtle Chelonia mydas. Mar Biol 56:147-154

Buchsbaum RN, Short FT, Cheney DP (1990) Phenolic-nitrogen interaction in eelgrass, Zostera marina L.: possible implication for disease resistance. Aquat Bot 37:291-297

Close DC, McArthur C (2002) Rethinking the role of many plant phenolics-protection from photodamage not herbivores? Oikos 99:166-172

Cruz-Rivera E, Hay ME (2000) Can quantity replace quality? Food choice compensatory feeding, and fitness of marine mesograzers. Ecology 81:201-219

Cyr H, Pace ML (1993) Magnitude and patterns of herbivory in aquatic and terrestrial ecosystems. Nature 361:148-150
Day JEL, Kyriazakis I, Rogers PJ (1998) Food choice and intake: towards a unifying framework of learning and feeding motivation. Nutr Res Rev 11:25-43

de la Higuera M (2001) Effects of nutritional factors and feed characteristics on feed intake. In: Houlihan D, Boujard T, Jobling $M$ (eds) Food intake in fish. Blackwell Science, Oxford, p 250-268

Duffy JE, Hay ME (1990) Seaweed adaptations to herbivory. BioScience 40:368-375

Duffy JE, Paul VJ (1992) Prey nutritional quality and the effectiveness of chemical defenses against tropical reef fishes. Oecologia 90:333-339

Forbes JM (1997) Control of appetite in animals. In: Houlihan D, Kressling A, Boujard T (eds) Voluntary food intake in fish. Blackwell Science, Oxford, p 23

Goh Y, Tamura T (1980) Olfactory and gustatory responses to amino acids in two marine teleosts-red sea bream and mullet. Comp Biochem Physiol 66C:217-224

Hara TJ (1994) The diversity of chemical stimulation in fish olfaction and gustation. Rev Fish Biol Fish 4:1-35

Hay ME (1984) Predictable spatial escapes from herbivory: how do these affect the evolution of herbivore resistance in tropical marine communities? Oecologia 64:396-407

Hay ME (1996) Marine chemical ecology: what's known and what's next? J Exp Biol Ecol 200:103-134

Hay ME, Fenical W (1988) Marine plant-herbivore interactions: the ecology of chemical defense. Annu Rev Ecol Syst 19:111-145

Hay ME, Fenical W, Gustafson K (1987) Chemical defense against diverse coral-reef herbivores. Ecology 68: 1581-1591

Hay ME, Kappel QE, Fenical W (1994) Synergisms in plant defenses against herbivores: interactions of chemistry, calcification, and plant quality. Ecology 75:1714-1726

Heckscher E, Hauxwell J, Jimenez E, Rietsma C, Valiela I (1996) Selectivity by the herbivorous amphipod Microdeutopus gryllotalpa among five species of macroalgae. Biol Bull 191:324-326

Hemminga MA, Harrison PG, van Lent F (1991) The balance of nutrient losses and gains in seagrass meadows. Mar Ecol Prog Ser 71:85-96

Herms DA, Mattson WJ (1992) The dilemma of plants: to grow or defend. Q Rev Biol 67:283-335

Jormalainen V, Honkanen T, Heikkila N (2001) Feeding preferences and performance of a marine isopod on seaweed hosts: costs of habitat specialization. Mar Ecol Prog Ser 220:219-230

Karban R, Baldwin IT (1997) Induced responses to herbivory. University of Chicago Press, Chicago

Kirsch KD, Valentine JF, Heck KL (2002) Parrotfish grazing on turltegrass (Thalassia testudinum): evidence for the importance of seagrass consumption in food web dynamics of the Florida Keys National Marine Sanctuary. Mar Ecol Prog Ser 227:71-85

Lamb CF (2001) Gustation and feeding behavior. In: Houlihan D, Boujard T, Jobling M (eds) Food intake in fish. Blackwell Science, Oxford, p 108-130

LaPointe BE, Matzie WR (1996) Effects of stormwater nutrient discharges on eutrophication processes in nearshore waters of the Florida Keys. Estuaries 19:422-435

Lincoln R, Newton T, Ehrlich P, Williams K (1982) Coevolution of the checkerspot butterfly Euphydryas chalcedona and its larval food plant Diplacus aurantiacus: larval response to protein and leaf resin. Oecologia 52:216-223

Littler MM, Littler DS (1980) The evolution of thallus form and survival strategies in benthic marine macroalgae: field and laboratory tests of a functional form model. Am Nat 
116:25-44

Littler MM, Taylor PF, Littler DS (1983) Algal resistance to herbivory on a Caribbean Barrier Reef. Coral Reefs 2: 111-118

Lobel PS (1981) Trophic biology of herbivorous reef fishes: alimentary $\mathrm{pH}$ and digestive capabilities. J Fish Biol 19: 365-397

Lobel PS, Ogden JC (1981) Foraging by the herbivorous parrotfish Sparisoma radians. Mar Biol 64:173-183

Manly BFJ (1993) Comments on design and analysis of multiple-choice feeding-preference experiments. Oecologia 93: 149-152

Mariani S, Alcoverro T (1999) A mutliple-choice feedingpreference experiment utilising seagrasses with a natural population of herbivorous fishes. Mar Ecol Prog Ser 189: 295-299

Marui R, Caprio J (1992) Teleost gustation. In: Hara TJ (ed) Fish chemoreception. Chapman \& Hall, London, p 171-198

Mattson WJ (1980) Herbivory in relation to plant nitrogen content. Annu Rev Ecol Syst 11:119-161

McGlathery KJ (1995) Nutrient and grazing influences on a subtropical seagrass community. Mar Ecol Prog Ser 122: 239-252

McMillian C (1984) The condensed tannins (proanthocyanidins) in seagrasses. Aquat Bot 20:351-357

McMillian C, Zapata O, Escobar L (1980) Sulphated phenolic compounds in seagrasses. Aquat Bot 8:267-278

McNeill S, Southwood TRE (1978) The role of nitrogen in the development of insect/plant relationships. In: Harborne J (ed) Biogeochemical aspects of plant and animal coevolution. Proceedings of the Phytochemical Society Symposium, p 78-89

Minkenberg O, Ottenheim J (1989) Effect of leaf nitrogen content of tomato plants on preference and performance of a leafmining fly. Oecologia 83:291-298

Moran N, Hamilton WD (1980) Low nutritive quality as defense against herbivores. J Theor Biol 86:247-254

Norin LL, Waern M (1973) The zone of low algal standing crop near Stockholm. Nutrients and their influence on the algae in the Stockholm Archipelago during 1970. Oikos 5: 179-184

Peckol P, Krane JM, Yates JL (1996) Interactive effects of inducible defense and resource availability on phlorotannins in the North Atlantic brown algae Fucus vesiculosus. Mar Ecol Prog Ser 138:209-217

Peterson CH, Renaud PE (1989) Analysis of feeding preference experiments. Oecologia 80:82-86

Preen A (1995) Impacts of dugong foraging on seagrass habitat: observational and experimental evidence for cultivation grazing. Mar Ecol Prog Ser 124:201-213

Randall JE (1968) Caribbean reef fishes. TFH Press, Jersey City, NJ

Ravn H, Pedersen MF, Borum J, Andary C, Anthoni U, Christophersen C, Neilsen PH (1994) Seasonal variation and distribution of two phenolic compound, rosmarinic acid and caffeic acid, in leave and roots-rhizomes of eelgrass (Zostera marina L.). Ophelia 40:51-61

Rice WR, Gaines SD (1994) 'Heads I win, tails you lose': testing directional alternative hypotheses in ecological and evolutionary research. Trends Ecol Evol 9:235-237

Roa R (1992) Design and analysis of multiple-choice feedingpreference experiments. Oecologia 89:509-515

Robblee MB, Zieman JC (1984) Diel variation in the fish fauna of a tropical seagrass feeding ground. Bull Mar Sci 34: $335-345$

Editorial responsibility: Kenneth Tenore (Contributing Editor), Solomons, Maryland, USA
Schroeder LA (1986) Changes in tree leaf quality and growth performance of lepidoptera larvae. Ecology 67:1628-1636

Shurin JB, Borer ET, Seabloom EW, Anderson K, Blanchette CA, Broitman B, Cooper SD, Halpern BS (2002) A crosssystem comparison of the strength of trophic cascades. Ecol Lett 5:785-791

Slansky FJ (1993) Nutritional ecology: the fundamental quest for nutrients. In: Stamp N, Casey T (eds) Caterpillars: ecological and evolutionary constraints on foraging. Chapman \& Hall, New York, p 29-91

Steinberg PD (1985) Feeding preferences of Tegula funebralis and chemical defenses of marine brown algae. Ecol Monogr 55:333-349

Steinberg PD, Edyvane K, de Nys R, Birdsey R, van Altena IA (1991) Lack of avoidance of phenolic rich brown algae by tropical herbivorous fish. Mar Biol 109:335-343

Steneck RS, Dethier MN (1994) A functional group approach to the structure of algal-dominated communities. Oikos 69:476-498

Stephens DW, Krebs JR (1986) Foraging theory. Princeton University Press, Princeton, NJ

Targett NM, Boettcher AA, Targett TE, Vrolijk NH (1995) Tropical marine herbivore assimilation of phenolic-rich plants. Oecologia 103:170-179

Targett TE, Targett NM (1990) Energetics of food selection by the herbivorous parrotfish Sparisoma radians: roles of assimilation efficiency, gut evacuation rate, and algal secondary metabolites. Mar Ecol Prog Ser 66:13-21

Thayer GW, Bjorndal KA, Ogden JC, Williams SL, Zieman JC (1984) Role of larger herbivores in seagrass communities. Estuaries 7:351-376

Valentine JF, Heck KL (1999) Seagrass herbivory: evidence for the continued grazing of marine grasses. Mar Ecol Prog Ser 176:291-302

Valentine JF, Heck KL (2001) The role of leaf nitrogen content in determining turtlegrass (Thalassia testudinum) grazing by a generalized herbivore in the northeastern Gulf of Mexico. J Exp Mar Biol Ecol 258:65-86

Vergeer LHT, Develi A (1997) Phenolic acids in healthy and infected leaves Zostera marina and their growth-limiting properties towards Labyrinthula zosterae. Aquat Bot 58: 65-72

Vergeer LHT, vander Velde G (1997) Phenolic content of daylight-exposed and shaded floating leaves of water lilies (Nymphaeaceae) in relation to infection by fungi. Oecologia 112:481-484

Wakefield RL, Murray SM (1998) Factors influencing food choice by the seaweed-eating marine snail Norrisia norrii (Trochidae). Mar Biol 130:631-642

Weinstein MP, Heck KL (1979) Icthyofauna of seagrass meadows along the Caribbean Coast of Panama and in the Gulf of Mexico: composition, structures, and community ecology. Mar Biol 50:97-107

Westoby M (1974) An analysis of diet selection by large generalist herbivores. Am Nat 108:290-304

Williams SL (1987) Competition between the seagrasses Thalassia testudinum and Syringodium filiforme in a Caribbean lagoon. Mar Ecol Prog Ser 35:91-98

Zapata O, McMillian C (1979) Phenolic acids in seagrasses. Aquat Bot 7:307-317

Zieman JC, Zieman RT (1989) The ecology of the seagrass meadows of the west coast of Florida: A community profile. US Fish Wild Serv Biol Rep 85:155

Zieman JC, Iverson RL, Ogden JC (1984) Herbivory effects on Thalassia testudinum leaf growth and nitrogen content. Mar Ecol Prog Ser 15:151-158

Submitted: October 27, 2003; Accepted: June 2, 2004

Proofs received from author(s): January 11, 2005 